\title{
Diagnosis of Mycoplasma from Starlings Lungs
}

\author{
Mohammad A. Hamad* (D), A.M. Al-Aalim (D) and Aamer Y.H. Alchalaby (D) \\ Department of Microbiology, College of Veterinary Medicine, University of Mosul, Mosul, Iraq.
}

\begin{abstract}
Starlings have tremendous economic and environmental impacts because they can spread pathogens to livestock and poultry. These birds act as mechanical and biological carriers for different types of pathogens from and to their original habitat. The goal of this study was to ascertain the presence of Mycoplasma gallisepticum (MG) in the starlings' lungs and confirm their diagnosis using the PCR technique. We altered the supplements that were added to Mycoplasma culture media by using calf serum instead of horse serum and sulphadimidine plus trimethoprim with nystatin instead of thallous acetate. Eighty-five starlings were bought from hunters in the spring of 2019, and their lungs were harvested and divided into two portions, one for Mycoplasma cultivation and the other for DNA extraction. Fifty-nine (69.4\%) samples were positive for Mycoplasma colonies, thereby yielding accurate results using alternative supplements in the culture media. PCR revealed the presence of $M y$ coplasma in $\mathbf{7 8 . 8 \%}$ lung samples, while MG was detected in only $\mathbf{4 3 . 3 \%}$ of the positive samples, indicating the presence of other species of Mycoplasma too. The current study is the first of its kind not only in Iraq but also in the world, investigating the presence of MG in the lungs of starling birds. This study revealed that MG is significantly prevalent in starlings and also suggests that other Mycoplasma species may be present in starlings.
\end{abstract}

Keywords: Starlings, Mycoplasma gallisepticum, PCR, culturing, calf serum.

*Correspondence: mahmah1073@gmail.com

(Received: 25 September 2019; accepted: 02 November 2019)

Citation: Mohammad A. Hamad, A.M. Al-Aalim and Aamer Y.H. Alchalaby, Diagnosis of Mycoplasma from Starlings Lungs, J Pure Appl Microbiol., 2019; 13(4):2273-2279. https://doi.org/10.22207/JPAM.13.4.41

(C) The Author(s) 2019. Open Access. This article is distributed under the terms of the Creative Commons Attribution 4.0 International License which permits unrestricted use, sharing, distribution, and reproduction in any medium, provided you give appropriate credit to the original author(s) and the source, provide a link to the Creative Commons license, and indicate if changes were made. 


\section{INTRODUCTION}

Starlings (Sturnus vulgaris Linnaeus) are migratory birds that visit our country every spring from Europe and Central Asia. These birds migrate in large swarms and at the end of spring, return to their original habitats. As a result of this annual migration, these birds serve as mechanical and biological carriers for different types of pathogens from and to their original habitat ${ }^{1-2}$. During this long migration, they pass through many countries and therefore, have a prominent role in transporting pollutants and microorganisms from and to these countries. There are local and international studies attributing the transmission of various microorganisms such as bacteria, viruses, and others, to these birds ${ }^{1,3-8}$.

Starlings have considerable economic and the environmental effects because they can spread pathogens to livestock and poultry by contaminating the fodder while invading fields to obtain food ${ }^{1,6-7,9}$, as well as polluting drinking water meant for livestock. These birds were placed in the Invasive Species Specialist Group's list of "100 of the World's Worst" biological invaders ${ }^{10}$.

Mycoplasma is a microorganism that causes many diseases in animals, such as infections of the respiratory system and joints, abortion, and mastitis. The economically important mycoplasmas in birds and poultry are Mycoplasma gallisepticum, M. synoviae, M. meleagridis, and other less important species like $M$. iowae, $M$. anatis, $M$. cloacae, and $M$. gallinarum ${ }^{11-12} . M$. gallisepticum causes chronic respiratory disease (CRD) in chickens (mainly in broiler chickens) and infectious sinusitis in turkeys ${ }^{12-13}$. Although CRD is a moderate respiratory disease, it becomes severe due to infections by synchronous pathogens. The disease is characterized by sneezing, coughing, rales, and nasal influx, and has a high morbidity and low mortality. Infectious sinusitis in turkeys is manifested by a swollen face and tacky exudate in the infraorbital sinuses ${ }^{12-13}$. M. synoviae is the causative agent of infectious synovitis in chickens and turkeys. The disease is a moderate respiratory disease, manifested by synovitis in chickens at 4-6 weeks of age and in turkeys at 10-12 weeks of age, bulging of the footpads and hocks, yellowish viscous exudate in the bursa (a fluid-filled sac) of the keel and hock and wing joints, and air sacculitis in case of concurrent infection with IB virus ${ }^{12-13}$.
The aim of this study was to detect the presence of Mycoplasma species, mainly M. gallisepticum, in the lungs of starlings to report if these birds play a role in the transmission of these pathogens to chickens and turkeys.

\section{MATERIALS AND METHODS Samples}

Eighty-five apparently healthy starling birds were bought from hunters in Mosul city in the spring of 2019. Their lungs were harvested under aseptic conditions and divided into two portions, one for Mycoplasma culture and the other for DNA extraction.

\section{Culture Media preparation}

The liquid and solid media were prepared using brain heart infusion (BHI) broth as a base to which agar agar was added for the solidification of liquid media. After autoclaving the media, the following supplements were added: yeast extract (10\%), calf serum (20\%) (14-16), $3 \mathrm{~mL}$ of penicillin $(100,000 \mathrm{IU} / \mathrm{mL})$ for inhibiting grampositive bacteria, and $3 \mathrm{~mL}$ of sulphadimidine $20 \%$ + trimethoprim $4 \%$ and nystatin for inhibiting the growth of gram-negative bacteria and fungi, respectively (instead of thallous acetate).

\section{Bacterial isolation}

A third of the lung was placed in $\mathrm{BHI}$ broth and incubated at $37^{\circ} \mathrm{C}$ for 7 days within a candle jar (17). Next, $0.1 \mathrm{~mL}$ of each broth sample was spread on $\mathrm{BHI}$ agar plates and incubated under the same conditions for 14 days ${ }^{12,17-18}$. Each solid plate was examined under a dissecting microscope to detect colonies with a fried egg appearance. Post examination, the Mycoplasma colonies were cultivated in $\mathrm{BHI}$ broth and stored at $-20^{\circ} \mathrm{C}$ for subsequent DNA extraction ${ }^{12,16}$.

\section{DNA extraction}

DNA extraction was performed from both, lung tissue and Mycoplasma colonies (1922). Mycoplasma genomic DNA was extracted from lung tissue and Mycoplasma colonies using the gSYNC ${ }^{\mathrm{TM}}$ Geneaid kit (Korea) following the manufacturer's instructions. PCR was used to detect the polymorphisms of the 16S rRNA gene using forward and reverse primers. To extract DNA from Mycoplasma colonies, the frozen BHI broths were thawed at room temperature and centrifuged at $2500 \mathrm{~g}$ for $30 \mathrm{~min}^{16}$, after which $100 \mu \mathrm{L}$ was taken from the sediment and subjected 
to the same procedure used for extraction of DNA from lung tissue $\mathrm{e}^{24-26}$.

\section{DNA Amplification}

Two coupled PCR primers were used (Table 1) that included genus-specific (Universal) and species-specific primers for the detection of genus Mycoplasma and M. gallisepticum ${ }^{27-28}$. Primers were synthesized by Bioneer Co. (Korea). The specificity of each PCR primer couple was confirmed using avian Mycoplasma strains.
PCR was performed using a total volume of $25 \mu \mathrm{L}$ comprising: $5 \mu \mathrm{L}$ of extracted DNA, $1 \mu \mathrm{L}$ of reverse and forward primer each, $2 \mu \mathrm{L}$ of $\mathrm{MgCl}_{2}$, $6 \mu \mathrm{L}$ ddD.W., and $10 \mu \mathrm{L}$ of 2.5' Mastermix solution (ready to use).

Thermocycler programs are mentioned in the Tables 2. Electrophoresis was performed using $10 \mu \mathrm{L}$ of the reaction solution on a $2 \%$ agarose gel with $0.8 \mu \mathrm{L}$ of ethidium bromide stain solution (10
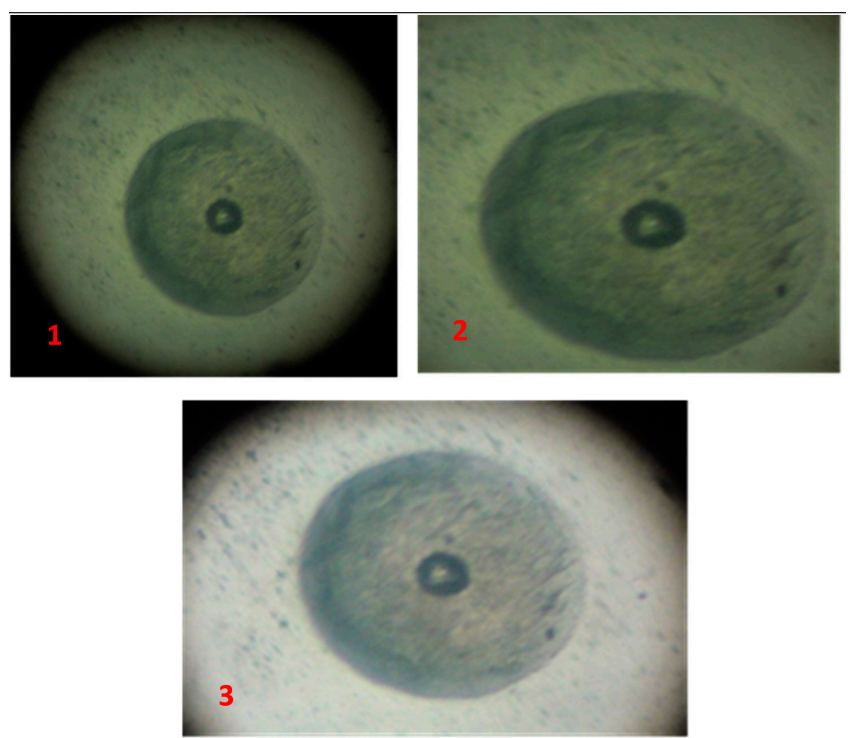

Fig. 1-3. Mycoplasmas colonies under dissecting and 10x light microscopes.

Table 1. Primers used to detect genus and Species of Mycoplasma gallisepticum strain

\begin{tabular}{lcc}
\hline Primer & & Sequence (5'-3') Product \\
\hline Detection & MYCO.-F & GGG-AGC-AAA-CAC-GAT-AGA-TAC-CCT \\
of Genus & & \\
Mycoplasma & MYCO.-R & TGC-ACC-ATC-TGT-CAC-TCT-GTT-ACC-CTC \\
Detection of & GALLI.-F & GAG-CTA-ATC-TGT-AAA-GTT-GGT-C \\
species M. & GALLI.-R & GCT-TCC-TTG-GGG-TTA-GCA-AC \\
gallisepticum & & \\
\hline
\end{tabular}

Table 2. PCR thermocycler program for detection of Genus Mycoplasma and species M. gallisepticum

\begin{tabular}{|c|c|c|c|c|}
\hline Cycle & $\begin{array}{l}\text { Temp. }{ }^{\circ} \mathrm{C} \text { for } \\
\text { Mycoplasma }\end{array}$ & $\begin{array}{c}\text { Temp. }{ }^{\circ} \mathrm{C} \text { for } M . \\
\text { gallisepticum }\end{array}$ & Time & Stage \\
\hline \multirow[t]{2}{*}{1} & 95 & 95 & $5 \mathrm{~min}$. & Initial DNA denaturation \\
\hline & 95 & 95 & 20 sec. & DNA denaturation \\
\hline \multirow[t]{2}{*}{30} & 59 & 53 & 30sec. & Primer annealing \\
\hline & 72 & 72 & 30sec. & Primer extension \\
\hline 1 & 72 & 72 & $5 \mathrm{~min}$. & Final extension \\
\hline 1 & 4 & 4 & “ & Cooling \\
\hline
\end{tabular}


$\mathrm{mg} / \mathrm{mL}$ ). DNA bands were detected at 245-312 $\mathrm{nm}$ using a UV transilluminator (Biometra, Germany).

\section{RESULTS}

All 85 samples were cultivated in modified culture media to detect Mycoplasma colonies. Fifty-nine (69.4\%) samples were positive for observable Mycoplasma colonies (Table 3, Fig. 1-3). Organisms from all fifty-nine $\mathrm{BHI}$ broths (positive for Mycoplasma colonies) belonged to the Mycoplasma genus, according to the PCR results (Fig. 4), while 24 of these 59 samples (40.7\%) were identified as M. gallisepticum (Fig. 5).

\section{Lung samples}

According to the PCR results, sixtyseven samples represented organisms from the

Table 3. Results of culturing of starlings lungs

\begin{tabular}{lccc}
\hline Samples & No. & Mycoplasma & $\%$ \\
Lungs & 85 & 59 & 69.4 \\
\hline
\end{tabular}

Mycoplasma genus (78.8\%), and among these, 29 samples were M. gallisepticum (43.3\%) (Table 4).

\section{DISCUSSION}

Starlings are migratory birds that play a major role in spreading infectious agents from one region to another. They are responsible for the transmission of infectious microorganisms in livestock and poultry farms via contamination of feed, causing economic losses (4, 29-31). The goal of the present study was to detect the presence of Mycoplasma, mainly, Mycoplasma gallisepticum, in the lungs of starlings.

Culture media isolation revealed that Mycoplasma was present in $69.4 \%$ of the starlings. This is a high rate of isolation for these organisms, which makes these birds significant carriers for Mycoplasma species.

The rate of detection of Mycoplasma directly from the lungs as per PCR results (87.8\%) was higher than the detection rate via culturing technique, suggesting that the detection and

Table 4. Presence of Mycoplasma in starlings lungs according to PCR results

\begin{tabular}{lccccc}
\hline No. Lungs & Mycoplasma & $\%$ & M. gallisepticum & $\%$ & $\%$ \\
\hline 85 & 67 & 78.8 & 29 & $43.3^{*}$ & $34.1^{* *}$ \\
\hline
\end{tabular}

* Rate of M. gallisepticum from the positive Mycoplasmal samples

** Rate of $M$. gallisepticum from the total lungs samples

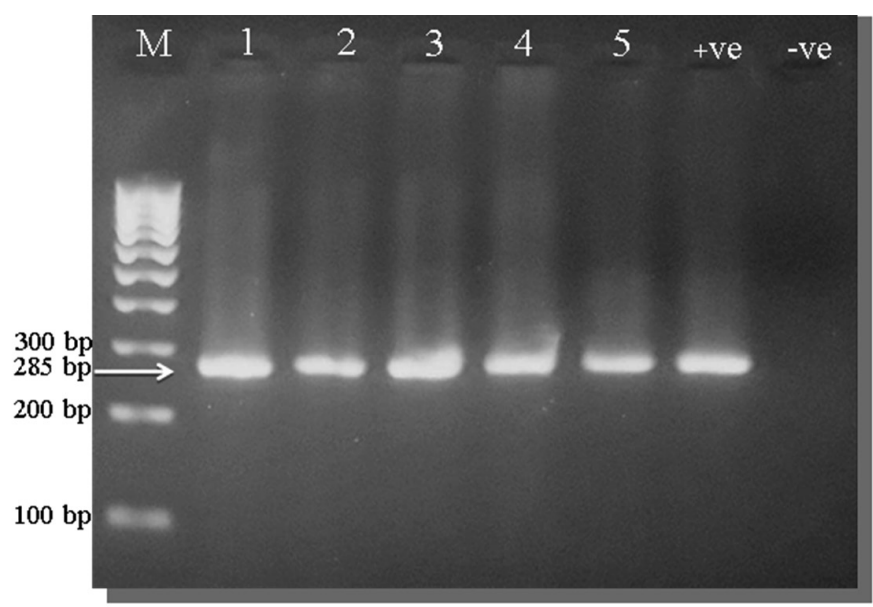

Fig. 4. Ethidium bromide-stained $2 \%$ agarose gel PCR amplification products of Mycoplasma spp. gene from Lung samples.

M: Marker, (1 - 5): Positive samples for genus Mycoplasma at $285 \mathrm{bp}$. molecular weight, +ve: Positive control for genus Mycoplasma, -ve: Negative control for genus Mycoplasma. 


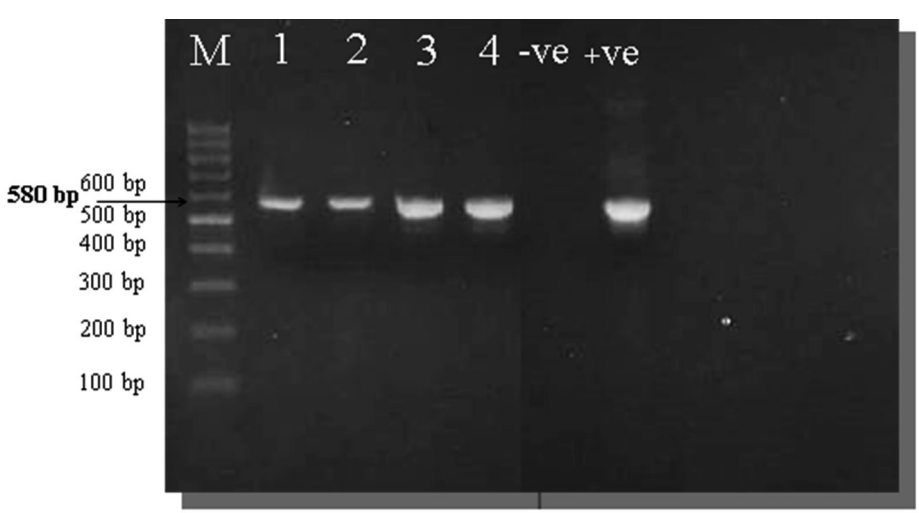

Fig. 5. Ethidium bromide-stained $2 \%$ agarose gel PCR amplification products of $M$. gallisepticum gene from Lung samples.

M: Marker, Samples (1-4): Positive samples for M. gallisepticum at 580 bp. molecular weight, +ve: Positive control for M. gallisepticum, -ve: Negative control for M. gallisepticum.

diagnosis of Mycoplasma species may be carried out directly from the tissues, especially lungs, without the need for culturing techniques, which take at least 14 days, thus reducing the time needed for the diagnosis of Mycoplasma infections ${ }^{16,20,22}$.

The current study used sulphadimidinetrimethoprim plus nystatin for the first time instead of thallous acetate as an inhibitor for the growth of gram-negative bacteria and fungi, and it provided excellent results for isolation without contamination. Also, this study is one of the few studies $^{14-16}$ to use calf serum instead of horse serum, providing ideal conditions and results for the cultivation of Mycoplasma. This could point towards a new trend in Mycoplasma research where researchers abandon the use of horse serum and use alternatives such as calf serum.

M. gallisepticum represented $43.3 \%$ of the total Mycoplasma spp. detected by the PCR technique (Table 4), which represents a high prevalence of this organism. This result reveals that the other Mycoplasma spp. (56.7\%) are also present in the starlings' lungs, which may include one or more of the following: $M$. synoviae, $M$. meleagridis, $M$. iowae, $M$. anatis, $M$. cloacae, and M. gallinarum ${ }^{12}$.

The rate of directly detecting of $M$. gallisepticum from lungs by using PCR is higher than the rate of detecting by culturing; this indicates the possibility of diagnosing these bacteria from tissues directly without the culturing of samples, which involves long periods of time for the cultivation of Mycoplasma (at least 14 days).

References to the isolation or detection of $M$. gallisepticum from lungs of starling birds are nonexistent, though there are reports about other Mycoplasma species in starlings, like $M$. sturni, which was isolated from the conjunctiva of European starlings ${ }^{32-33}$. Most scientific articles mention the isolation and diagnosis of $M$. gallisepticum from finches and other species of birds (34-39), making this study the first to have detected and isolated $M$. gallisepticum from starlings in general and from their lungs in particular.

In conclusion, the results of this study elucidate a high presence of $M$. gallisepticum in the lungs of starlings, and this may be the only study that confirms the presence of these bacteria in the lungs of these birds. It also proves the possibility of using alternative supplements to be added to the culture media for Mycoplasma, in terms of alternate serum and antimicrobial types. Further, the current study has demonstrated the possibility of diagnosing Mycoplasma directly from tissues without the need for culturing.

\section{ACKNOWLEDGMENT}

The authors would like to thank college of the Veterinary Medicines/ University of Mosul, Iraq for their support. The Authors are also grateful to Dr. Omar Hashim Sheet for his sincere efforts. 


\section{CONFLICT OF INTEREST}

The authors declare that there is no conflict of interest.

\section{AUTHORS' CONTRIBUTION}

All authors listed have made a substantial, direct and intellectual contribution to the work, and approved it for publication.

\section{FUNDING}

None.

\section{DATA AVAILABILITY}

All datasets created or investigated during this study are involved in the manuscript and/or the Supplementary Files.

\section{ETHICS STATEMENT}

This article does not contain any studies with human participants or animals performed by any of the authors.

\section{REFERENCES}

1. Homan HJ, Johnson RJ, Thiele JR, and Linz GM. European Starlings. WDM Technical Series. U.S. Department of Agriculture Animal \& Plant Health Inspection Service Wildlife Services. Electronic version, 2017; 1-26.

2. Linz, G., R. Johnson, and J. Thiele. European starlings. pp. 311-332. In: W.C. Pitt, J.C. Beasley, and G.W Witmer, editors. Ecology and Management of terrestrial vertebrate invasive species in the United States. CRC Press, Boca Raton, FL, 2018. https://doi. org/10.1201/9781315157078-15

3. Summers RW, Pritchard, GC, Brookes HBL. The Possible role of starlings in the spread of TGE in pigs. Bird Control Seminars Proceedings, 1983; Paper 256.

4. Gaukler SM, Homan HJ, Dyer NW, Linz GM, and Bleier WJ. Pathogenic diseases and movements of wintering European starlings using feedlots in Central Kansas. Proc 23rd Verteb Pest Conf, 2008; 280-282. https:// doi.org/10.5070/V423110659

5. Daniels MJ, Hutchings MR and Greig A. The risk of disease transmission to livestock posed by contamination of farm stored feed by wildlife excreta. Epidemiol Infect., 2010; 130(3): 561-568. https://doi. org/10.1017/S0950268803008483

6. Carlson JC, Engeman RM, Hyatt DR, Gilliland RL, Deliberto TJ, Clark L, Bodenchuk MJ, and Linz GM, Efficacy of European starling control to reduce Salmonella enterica contamination in a concentrated animal feeding operation in the Texas panhandle. BMC Veterinary Research, 2011a; 7(9): 2-10. https://doi. org/10.1186/1746-6148-7-9

7. Carlson JC, Franklin AB, Hyatt DR, Pettit SE, and Linz $\mathrm{GM}$. The role of starlings in the spread of salmonella within concentrated animal feeding operations. J. of Applied Ecology, 2011b; 48: 479-486. https://doi. org/10.1111/j.1365-2664.2010.01935.x

8. Hamad MA, Ali HH, Al-Aalim AM, AL- Dabbagh SY. Diagnosis of Salmonella spp. from internal organs of Quails and Starlings birds. 2nd Scientific Conference For Faculty of Vet. Med. Univ. of Kufa. 2014; 198-204. 9. Berger S, Disko R, and Gwinner H. Bacteria in starling nests. J. Ornithol., 2003; 144: 317-322. https://doi. org/10.1007/BF02465631

10. Lowe S, Browne M, Boudjelas S, and DePoorter M. 100 of the world's worst invasive alien species: a selection from the global invasive species database. The Invasive Species Specialist Group (ISSG) a specialist group of the Species Survival Commission (SSC) of the World Conservation Union, 2004.

11. Quinn PJ, Carter ME, Markey B, and Carter GR. Clinical veterinary microbiology, 2004.; 209-236. MOSBY “An imprint of Elsevier Limited", USA.

12. Quinn PJ, Markey BK, Leonard FC, FitzPatrick ES, Fanning S and Hartigan PJ. Veterinary Microbiology and Microbial Diseases, 2011; 67-69. 2nd Ed. John Wiley \& Sons Ltd. UK.

13. Saif YM, Fadly AM, Glisson JR, McDougald LR, Nolan LK and Swayne DE, Diseases of Poultry, 2008; 36, 619-674. 12th Ed. Blackwell Publishing. State Avenue, Ames, lowa 50014, USA.

14. Hamad MA and AL-Jumaa ZM. Isolation and identification of Mycoplasma from cases of pneumonia in feedlot lambs. Assiut Vet. Med. J. Vol., 2014; 60(142): 7-13.

15. AL-Jumaa ZM, Hamad MA. Bacteriological and histological study for atypical pneumonia in feedlot lambs. Basrah Journal of Veterinary Research, 2018; 17(3):71-85.

16. AL-Jumaa ZM. Isolation and identification of Mycoplasma ovipneumoniae from cases of pneumonia in feedlot lambs in Mosul city. M.Sc. thesis, Department of Microbiology; College of Vet. Med.- University of Mosul; Mosul-Iraq, 2017.

17. Konemann EW, Allen SD, Janda WM, Schreck PC, and Winn WC. Color atlas and textbook of diagnostic microbiology, $5^{\text {th }}$ ed. Lippincot-Raven Publisher. Philadelphia. USA, 1997.

18. Songer JG, and Post KW. Veterinary microbiology: Bacterial and fungal agents of animal disease, 2005; 21-35,131-137. Elsevier Inc.

19. Butler JA, Cole C, Pinnow J, Thomson U, Sharon L, and Rosenbusch $\mathrm{F}$. Use of arbitrarily primed polemerase chain reaction to investigate Mycoplasma bovis out breaks. Vet. Microb., 2001; 78: 175-181. https://doi. org/10.1016/S0378-1135(00)00286-8

20. Hotzel H, Frey J, Bashiruddin J, and Sachse K. Detection and differentiation of ruminant Mycoplasmas. Methods in Molecular Biology, 2003; 216-213-245.

21. Viljoen GJ, Louis $H$, and Crawther JR. Molecular Diagnostic PCR Handbook, 2005; 178-187. $1^{\text {st }}$ ed. Springer. Dordrecht, Netherlands.

22. Kilic $A$, Kalender $H$, Eroksuz $H, M u z A$, and Tasdemir B. Identification by culture, PCR and immunohistochemistry of Mycoplasmas and their molecular typing in sheep and lamp lungs with 
pneumonia in Eastern Turkey. Trop. Anim. Health Prod., 2013; 45: 1525-1531. https://doi.org/10.1007/ s11250-013-0394-3

23. Santos EM, Paula JFR, Motta PMC, Heinemann MB, Leite RC, Haddad JPA, Del Puerto HL, Reis JKP. Comparison of three methods of DNA extraction from peripheral blood mononuclear cells and lung fragments of equines, Gene and Mol. Res., 2010; 9(3): 1591-1598. https://doi.org/10.4238/vol9-3gmr818

24. Almeda RA, Wannemuchier MJ, Rosenbusch RF. Interaction of Mycoplasma dispar with bovine alveolar macrophages. Infect. Immun., 1992; 60: 2914-2919.

25. Mudahi-Orenstein S, Levischin S, Geary SJ, Yogev D. Cyadherence-deficient mutants of Mycoplasma gallisepticum generated by Transposon Mutagenesis. Infect Immun., 2003; 71: 3812-3820. https://doi. org/10.1128/IAI.71.7.3812-3820.2003

26. Al-Momani W, Halabab M, Abo-Shehada M, Miles K, McAuliffe L, and Nicholas R. Isolation and molecular identification of small ruminant Mycoplasma in Jordan. Small Animal Res., 2006; 65: 106-112. https://doi. org/10.1016/j.smallrumres.2005.05.022

27. Aghabalaei E, Hedayati MH, Shapouri R, Ghorbani M, Nejati M, Sadati $M$ and Ahmadi H. Detection of Urogenital Mycoplasmas using Culture and PCR. Journal of Advances in Bioresearch SOE, INDIA, 2012; 3(4): 181- 184.

28. Malekhoseini G, Pourbakhsh SA, Homayounimehr AR, Zolfeghari MR, Ashtari A, and Abtin AR. Simultaneous identification of Mycoplasma gallisepticum and Mycoplasma synoviae by duplex PCR assay. Immunol. Case Rep., 2017; 1(1): 12-16.

29. Koenig WD. European Starlings and Their Effect on Native Cavity-Nesting Birds. Conservation Biology, 2003; 17(4): 1134-1140. https://doi.org/10.1046/ j.1523-1739.2003.02262.x

30. Linz GM, Homan HJ, Gaukler SM, Penry LB, and Bleier WJ. European starlings: a review of an invasive species with far-reaching impacts. Managing Vertebrate Invasive Species, 2007; 24. https: //digitalcommons. unl.edu/nwrcinvasive/24.

31. Gaukler SM, Linz GM, Sherwood JS, Dyer NW, Bleier WJ, Wannemuehler YM, Nolan LK, and Logue CM. Escherichia coli, Salmonella, and Mycobacterium avium subsp. paratuberculosis in wild European starlings at a Kansas cattle feedlot. Avian Diseases, 2009; 53(4): 544-551. https://doi.org/10.1637/8920050809-Reg.1

32. Forsyth MH, Tully JG, Gorton TS, Hinckley L, Frasca $\mathrm{S} J \mathrm{~J}$, van Kruiningen HJ, Geary SJ. Mycoplasma sturni sp. nov., from the conjunctiva of a European starling (Sturnus vulgaris). Int. J. Syst. Bacteriol., 1996; 46(3):716-719. https://doi.org/10.1099/0020771346-3-716

33. Frasca S, Hinckley L, Forsyth MH, Gorton TS, Geary $\mathrm{SJ}$, and Van Kruiningen HJ. Mycoplasmal Conjunctivitis in a European Starling. J. of Wildlife Diseases, 1997; 33(2): 336-339. https://doi.org/10.7589/0090-355833.2.336

34. Ley DH, Berkhoff JE, and McLaren JM. Mycoplasma gallisepticum isolated from house finches (Carpodacus mexicanus) with conjunctivitis. Avian Dis., 1996; 40(2): 480-483. https://doi.org/10.2307/1592250

35. Grodio JL, Hawley DM, Osnas EE, Ley DH, Dhondt KV, Dhondt AA, Schat KA. Pathogenicity and immunogenicity of three Mycoplasma gallisepticum isolates in house finches (Carpodacus mexicanus). Vet. Microbiol., 2011; 24(155): 53-61. https://doi. org/10.1016/j.vetmic.2011.08.003

36. Hurtado PJ. Within-host dynamics of mycoplasma infections: conjunctivitis in wild passerine birds. J. Theor. Biol., 2012; 7(306): 73-92. https://doi. org/10.1016/j.jtbi.2012.04.018

37. Dhondt AA, Dhondt KV, Hochachka WM. Response of black-capped chickadees to house finch Mycoplasma gallisepticum. PLoS One, 2015; 10(4):1-9. https://doi. org/10.1371/journal.pone.0124820

38. Staley M and Bonneaud C. Immune responses of wild birds to emerging infectious diseases. Parasite Immunol., 2015; 37(5): 242-54. https://doi. org/10.1111/pim.12191

39. Vinkler $M$, Leon AE, Kirkpatrick L, Dalloul RA, and Hawley DM. Differing House Finch Cytokine Expression Responses to Original and Evolved Isolates of Mycoplasma gallisepticum. Front Immunol., 2018; 22(9): 1-16. https://doi.org/10.3389/ fimmu.2018.00013 